\title{
Prediction of acid mine drainage generation potential of various lithologies using static tests: Etili coal mine (NW Turkey) as a case study
}

\author{
Deniz Sanliyuksel Yucel • Alper Baba
}

Received: 9 September 2015 / Accepted: 29 June 2016/Published online: 19 July 2016

(C) Springer International Publishing Switzerland 2016

\begin{abstract}
The Etili neighborhood in Can County (northwestern Turkey) has large reserves of coal and has been the site of many small- to medium-scale mining operations since the 1980s. Some of these have ceased working while others continue to operate. Once activities cease, the mining facilities and fields are usually abandoned without rehabilitation. The most significant environmental problem is acid mine drainage (AMD). This study was carried out to determine the acid generation potential of various lithological units in the Etili coal mine using static test methods. Seventeen samples were selected from areas with high acidic water concentrations: from different alteration zones belonging to volcanic rocks, from sedimentary rocks, and from coals and mine wastes. Static tests (paste $\mathrm{pH}$, standard acid-base accounting, and net acid generation tests) were performed on these samples. The consistency of the static test results showed that oxidation of sulfide minerals, especially pyrite - which is widely found not only in the alteration zones of volcanic rocks but also in the coals and mine wastes - is the main factor controlling the generation of AMD in this mine. Lack of carbonate minerals in the region also increases the occurrence of AMD.
\end{abstract}

\section{S. Yucel $(\bowtie)$}

Department of Geological Engineering, Canakkale Onsekiz Mart University, Canakkale, Turkey

e-mail: denizsyuksel@comu.edu.tr

\section{A. Baba}

Department of Civil Engineering, Izmir Institute of Technology, Izmir, Turkey
Keywords Acid generation prediction - Acid mine drainage $\cdot$ Etili coal mine $\cdot$ Static tests

\section{Introduction}

Acid mine drainage (AMD) from waste rock, tailings, and other mine components is the most important environmental problem in the mining industry (Lawrence and Scheske 1997). AMD is often characterized by high concentrations of metals and sulfates in solution and by generally low $\mathrm{pH}$ values (Mendez-Ortiz et al. 2007). These acidic solutions can potentially contaminate water resources, as well as soils (Skousen 1995; Morin and Hutt 1997; Mendez-Ortiz et al. 2007). AMD has a long history, dating back thousands of years to Phoenician times when the Iberian Pyrite Belt in Spain, from where the Rio Tinto ("Red River") flows, was first exploited (Miller 1998; Usher and Vermeulen 2006). In the past, little attention was paid to acid generation, leading to long-term environmental problems associated with water discharges from old mine excavations and from piles of pyrite-bearing waste rocks (Hughes et al. 2007). Currently, handling and long-term storage of pyrite-bearing waste rocks are important issues at mine sites, and details of waste rock stack construction are an integral part of mine design, even before mines are opened (Sengupta 1993; Tran et al. 2003; Williams et al. 2003; Hughes et al. 2007). There are over 200,000 AMD sites within the USA (Hochella et al. 1999); more 
than $5000 \mathrm{~km}$ of water courses are polluted by contaminated drainage from abandoned mines in Europe (Younger et al. 2002; DiLoreto et al. 2016). The most expensive aspects of some mining operations involve long-term water management and treatment because of their acidic $\mathrm{pH}$ and/or unacceptably high aqueous metal concentrations (Morin and Hutt 2006). The time period for such management and treatment can span decades to centuries (Morin and Hutt 1997, 2001, 2006). Given that mineralogy and other factors affecting AMD formation are highly variable from site to site, predicting the potential for AMD can be exceedingly challenging and costly (U.S. EPA 1994; Yeheyis et al. 2009).

Static tests used to evaluate the acid generation potential of rocks and mine wastes are critical to determine the environmental impact of a mine site and to choose a waste management method to minimize that impact (Ritcey 1989; Morin and Hutt 1997; Bussiere et al. 2004; Benzaazoua et al. 2004; Yeheyis et al. 2009). Details of these tests are documented (Sobek et al. 1978; Smith et al. 1992; Morin and Hutt 1997; White et al. 1999; Mitchell 2000; Jambor 2003; Mills 2007; Lottermoser 2010). Static tests are short-term, relatively low-cost tests developed to provide an estimate of the capacity of mine waste to produce acid and to neutralize acid (Lapakko 2002). A large number of these tests can be performed to characterize the various mine rock units and from this to select samples for kinetic testing. To develop waste management plans that will confidently allow permitting to proceed and the acceptance of closure measures, proponents and operators must characterize the various wastes and other components from current or proposed mining activities to predict future performance of the materials when disposed of under ambient conditions (Lawrence and Scheske 1997). In dealing with environmental aspects of the potential exploitation of mineral and coal deposits, such as the ongoing disposal of wastes at operating mines, preparation for mine closures, and the remediation of abandoned sites, it is essential to predict the geochemical behavior of the wastes on their exposure to weathering (Jambor et al. 2002).

The Etili neighborhood in Can County (northwestern Turkey) has large reserves of coal and has been the site of many small- to medium-scale mining operations since the 1980s. Some of these have now ceased working while others continue to operate. Once activities have ceased, the mining facilities and fields are usually abandoned without rehabilitation. As a consequence of human intervention in the natural structures and topography of the earth's surface, large holes and deterioration have developed in these areas. Artificial lakes can occur as a result of both surface discharge and underground leakage into abandoned open pits; over time, these lakes become acidic $(\mathrm{pH}$ $<4)$ and accumulate high metal concentrations (e.g., $\mathrm{Al}$ and $\mathrm{Fe}$ ). The geological characteristics of the region and the limnological and hydrogeochemical characteristics of these acid mine lakes have been studied in detail (Gunduz and Baba 2008; Gurdal 2011; Gurdal and Bozcu 2011; Okumusoglu and Gunduz 2013; Sanliyuksel Yucel and Baba 2013; Sanliyuksel Yucel et al. 2014, 2016), but the acid generation potential of different lithological units has not yet been studied. In this work, static test methods were employed to investigate the Etili coal mine for acid generation potential of the various lithological units and mine wastes. The site provides an excellent comparison with other problematic coal mining sites.

\section{Site description}

The Etili open pit coal mine is located in Can County, approximately $40 \mathrm{~km}$ from Canakkale, Turkey (Fig. 1a). The lithological units can be classified into two groups: Oligocene-aged Can volcanic rocks (Ercan et al. 1995) and Early-Middle Mioceneaged Can formation (Hezarfen, Feasibility report of Çan-Çanakkale coal deposits, unpublished) (Fig. 1b). Can volcanic rocks (andesite, andesitic tuff, agglomerate, and trachyandesite lava), which comprise the basement lithology of the study area, have undergone different types of hydrothermal alteration, including silicic and argillic alterations. Can formation sedimentary rocks were deposited by calc-alkaline volcanic activity (Siyako et al. 1989). The Can formation contains heterogeneous lithologies, such as conglomerate, sandstone, claystone, coal, organic claystone, and tuff. Low-calorific-value coal is extracted by several private mining companies for local heating purposes. 

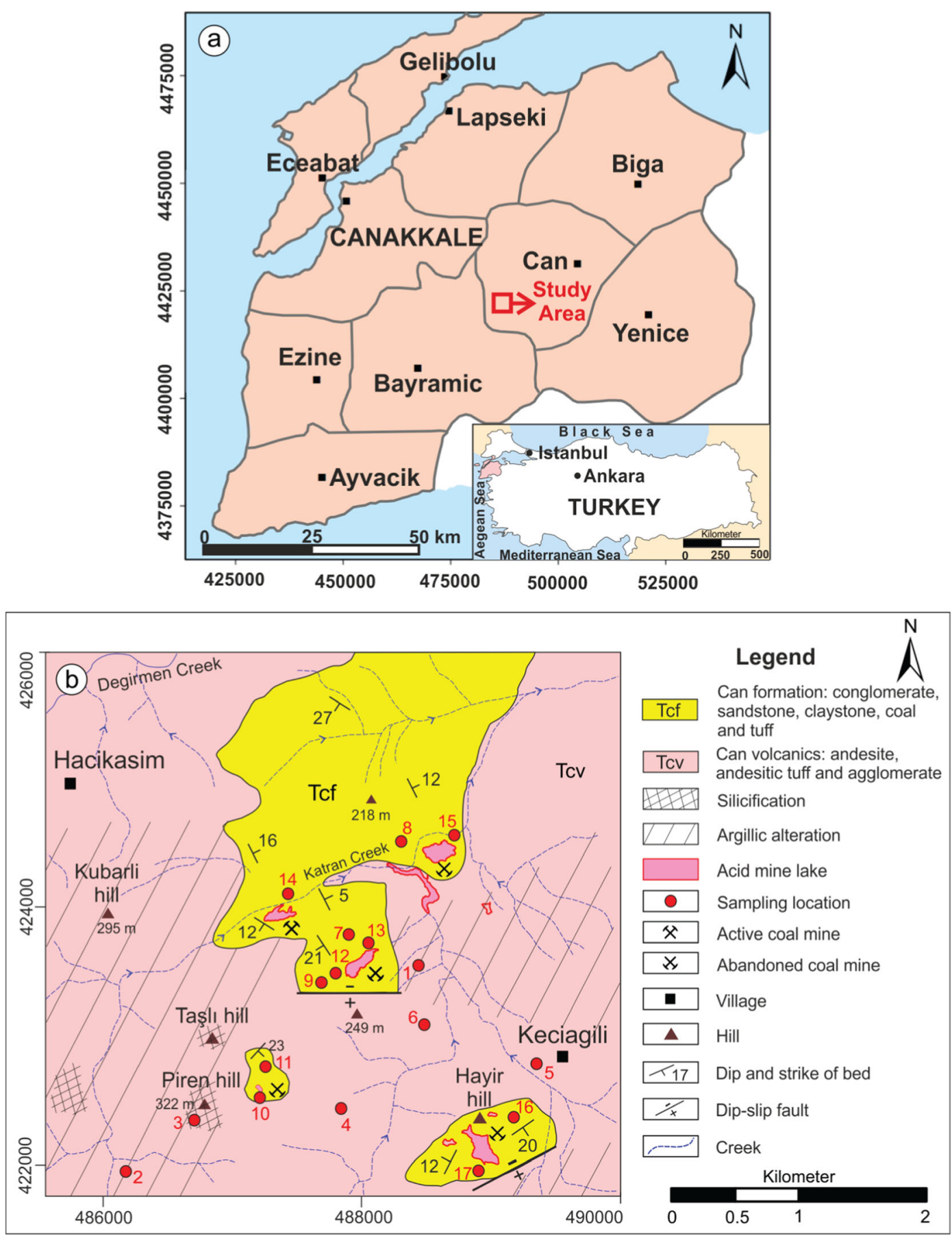

Fig. 1 a Location map and b geological map of the study area (Sanliyuksel Yucel et al. 2016) and sampling locations

The Etili coal mine contained nine acid mine lakes (AMLs) (Fig. 2), which had a total area of 11.42 ha in November 2014, according to unmanned air vehicle data (Yucel and Turan 2016). One lake was emptied because of reopening mining activities and the remaining eight AMLs covered 9.82 ha in October 2015 (Yucel and Turan 2016). The $\mathrm{pH}$ and electrical conductivity values of the AMLs ranged from 3.01 to 4.24 and from 2380 to $5690 \mu \mathrm{S} \mathrm{cm} \mathrm{cm}^{-1}$, respectively (Sanliyuksel Yucel and Yucel 2016). The maximum Fe 

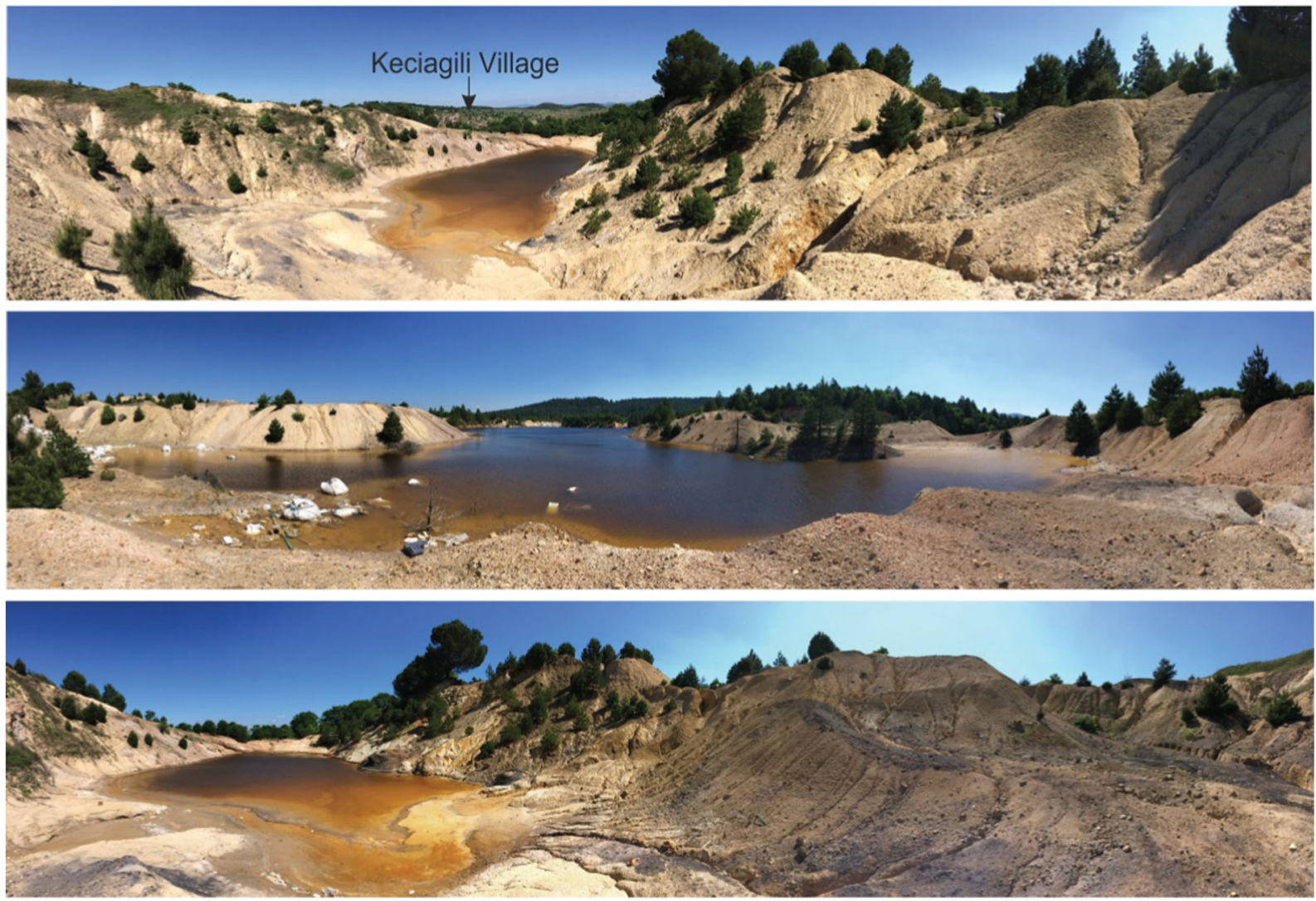

Fig. 2 Panoramic snapshot from AMLs and waste heaps from Etili coal mine

and $\mathrm{Al}$ concentrations of the lakes were 338 to $357 \mathrm{mg} \mathrm{L}^{-1}$, respectively (Sanliyuksel Yucel et al. 2014). The lakes are classified as class IV with respect to their $\mathrm{pH}, \mathrm{SO}_{4}, \mathrm{Al}, \mathrm{Fe}, \mathrm{Mn}, \mathrm{Ni}$, and $\mathrm{Zn}$ concentrations, in accordance with the Water Pollution Control Regulations in Turkey (SKKY 2004); in other words, they are considered to be highly polluted (Sanliyuksel Yucel and Yucel 2016).

The AMLs are situated upstream of the Kocacay River watershed of Can County, which is rich in water resources. Local drinking and irrigation water resources are supplied from an alluvium aquifer that outcrops along the Kocacay River (Okumusoglu and Gunduz 2013; Sanliyuksel Yucel et al. 2016). There are many small creeks, such as the Katran Creek, connected to the Kocacay River, where the water has a neutral $\mathrm{pH}$. Because the lakes drain into Katran Creek, the $\mathrm{pH}$ of the creek is decreasing. Sanliyuksel Yucel and Baba (2013) stated that the creeks around Etili coal mine ranged from $\mathrm{pH} 2.9$ to 5.8. They also have a reddishbrown color because of the high $\mathrm{Fe}$ concentration
(161 mg L $\left.{ }^{-1}\right) ; \mathrm{Al}, \mathrm{Mn}$, and $\mathrm{Ni}$ concentrations of creek water have reached 212,40 , and $0.8 \mathrm{mg} \mathrm{L}^{-1}$, respectively (Sanliyuksel Yucel and Yucel 2016). Local media has widely reported on the death of aquatic life as a result of seepage and discharge of the lake waters into surface waters in the Etili region. This site represents an important risk to drinking water resources via water flow paths from this low-pH, high-metal concentration source.

\section{Materials and methods}

Field studies and sampling

The spatial distribution of the sampling locations is given in Fig. 1b. Based on field observations and previous studies, 17 representative rock samples were collected from exposed lithological units, particularly mining faces and rock outcrops, and mine waste samples were obtained from coal mine waste dumps to assess their acid generation potential. Approximately $5 \mathrm{~kg}$ of 
each sample was collected in plastic bags. The sampling includes specifications for chain of custody procedures and documentation consistent with quality assurance and quality control (QA/QC) procedures.

\section{Experimental methods}

The experimental procedures for the static tests differed with respect to the aging period, sample grain size, and type and amount of acid used. Replicate samples, standards, certified reference materials, and blanks routinely submitted to ensure and confirm that the analytical results are of acceptable quality in all experiments. Details of the experimental procedures are provided below.

\section{Paste $\mathrm{pH}$ and electrical conductivity}

The paste $\mathrm{pH}$ test is used to determine the acidic nature of rock and waste samples and provides an indication of immediate $\mathrm{pH}$ characteristics on mixing a crushed sample with water (Weber et al. 2006a). Lapakko (2002) emphasized that paste $\mathrm{pH}$ is a common and simple field test used to assess the presence of acid-soluble salts in mine wastes. Electrical conductivity (EC) provides an indirect measure of the quantity of water-soluble salts in the sample. A $\mathrm{pH}$ value below 4 generally indicates that the sample is acid generating and an EC value of greater than $2000 \mu \mathrm{S} \mathrm{cm}^{-1}$ indicates a high level of total dissolved solids in the waste leachates (Lottermoser 2010).

Paste $\mathrm{pH}$ tests were performed to obtain preliminary information on the immediate reactivity of minerals present in each sample using the Sobek procedure (Sobek et al. 1978). Before testing, the samples were ground to a particle size of less than $1 \mathrm{~mm}$ (18 mesh). The samples (20 g each) were placed in $50-\mathrm{mL}$ beakers. Ultrapure water of the same mass as the sample (20 $\mathrm{mL}, 1: 1 \mathrm{solid} /$ solution ratio) was added with the aid of a digital burette and mixed with a glass rod for $10 \mathrm{~s}$ to make a paste. The paste $\mathrm{pH}$ was then measured by inserting a $\mathrm{pH}$ electrode into the paste. The first measurement was made at $10 \mathrm{~min}$, with measurements repeated after $20 \mathrm{~min}, 1 \mathrm{~h}, 24 \mathrm{~h}, 48 \mathrm{~h}, 1$ week, 2 weeks, and 3 weeks. The reaction was allowed to continue after each measurement by providing an oxygen environment: the solution was mixed for $10 \mathrm{~s}$ and $\mathrm{pH}$ and EC were measured with a Multi 340i instrument
(Wissenschaftlich-Technische Werkstätten, Weinheim). The experiments were concluded at the end of the third week.

\section{Standard acid-base accounting}

Standard acid-base accounting (ABA) is the most commonly used static test to predict AMD from mine wastes (Yeheyis et al. 2009). The ABA test evaluates the balance between maximum acidgenerating processes (oxidation of sulfide minerals) and acid-neutralizing processes (dissolution of alkaline carbonates, displacement of exchangeable bases, and weathering of silicates) (Sobek et al. 1978; Ritcey 1989; Skousen et al. 2002; Yeheyis et al. 2009; Banerjee 2014). The maximum acidproducing potential (MAP) of the sample is calculated on the basis of its total sulfur (S) content: for each $1 \% \mathrm{~S}$ contained in the material, 31.25 metric tons $(t)$ of calcium carbonate are required for neutralizing the sulfuric acid produced from $1000 \mathrm{t}$ of the material (Sobek et al. 1978; Skousen et al. 2000). The MAP value (in $\mathrm{kg} \mathrm{CaCO}_{3} / \mathrm{t}$ ) was calculated according to the formula proposed by Sobek et al. (1978): $\mathrm{MAP}=\mathrm{S}(\mathrm{wt} \%) \times 31.25$. This calculation assumes that all $\mathrm{S}$ is contained in pyrite, which is a reasonable approximation (Sobek et al. 1978; Weber et al. 2004, 2006a, b; Hughes et al. 2007).

The neutralization potential (NP) test measures the amount of acid that the sample can neutralize (Lottermoser 2010). This is determined by analyzing the acid consumption of a sample prepared with a particle size less than $250 \mu \mathrm{m}$ (60 mesh). Accurately weighed $0.5 \mathrm{-g}$ sample was prepared for a fizz test then a few drops of $25 \% \mathrm{HCl}$ were dropped onto it. The density and size of the bubbles formed by the reaction that occurred when the acid solution contacted the sample were observed, and the appropriate volume and molarity of the acid to be used in the test were determined from Table 1. Accurately weighed 2-g samples were placed in a $250-\mathrm{mL}$ conical flask, and the volume and molarity of acid identified from Table 1 were added. The flask was then heated in a water bath at a fixed temperature of $85{ }^{\circ} \mathrm{C}$ and shaken at 5min intervals. The flask was left in the water bath for at least $2 \mathrm{~h}$ or until the reaction was completed (until no further bubbles or gas were released). Pure water was then added to make up the volume 
Table 1 Description of fizz rating and amounts and strengths of $\mathrm{HCl}$ (Sobek et al. 1978)

\begin{tabular}{llll}
\hline Fizz rating & Description & Amount of acid (mL) & Strength of acid (M) \\
\hline None & No reaction & 20 & 0.1 \\
Slight & Minimal reaction; a few bubbles per second to many fine bubbles & 40 & 0.1 \\
Moderate & Active bubbling with only a small amount of splashing & 40 & 0.5 \\
Strong & Very active bubbling that includes substantial splashing & 80 & 0.5 \\
\hline
\end{tabular}

to $125 \mathrm{~mL}$ and the solution left in the water bath for another minute. The flask was then firmly closed and left to cool to ambient temperature (28-30 $\left.{ }^{\circ} \mathrm{C}\right)$. Standardized $\mathrm{NaOH}$ solution of the same concentration as the $\mathrm{HCl}$ was added to the cooled solution and back-titrated to $\mathrm{pH} 7.0$ to determine the amount of acid consumed by the sample.

Acid consumed in the digestion of the neutralizing species was used to calculate NP according to (MendezOrtiz et al. 2007):

$\mathrm{NP}=\frac{50 \times\left[\left(a_{\mathrm{M}} \times v_{\mathrm{A}}\right)-\left(b_{\mathrm{M}} \times v_{\mathrm{B}}\right)\right]}{s_{\mathrm{W}}}$,

where NP is the neutralization potential $\left(\mathrm{kg} \mathrm{CaCO}_{3} \mathrm{t}^{-1}\right)$, $a_{\mathrm{M}}$ is the molarity of acid (M), $b_{\mathrm{M}}$ is the molarity of base $(\mathrm{M}), v_{\mathrm{A}}$ is the volume of acid $(\mathrm{mL}), v_{\mathrm{B}}$ is the volume of the base $(\mathrm{mL})$, and $s_{\mathrm{W}}$ is the mass of the sample $(\mathrm{g})$.

\section{Net acid generation test}

The net acid generation (NAG) test is based on the principle that hydrogen peroxide accelerates the oxidation of iron sulfide minerals (Miller et al. 1990). The acid produced dissolves neutralizing minerals present, and the net result of the acid production and neutralization can be measured directly (Brough et al. 2013). This test does not require $\mathrm{S}$ determinations and is therefore more readily conducted in a field laboratory than other static tests (Lapakko 2002).

Samples with particle sizes less than $75 \mu \mathrm{m}$ (200 mesh) were prepared. The $\mathrm{pH}$ of the $\mathrm{H}_{2} \mathrm{O}_{2}$ must be between 4 and 7; if the $\mathrm{pH}$ is below 4 , it is recommended that dilute $\mathrm{NaOH}$ be added until a value between $\mathrm{pH} 4$ and 6 is reached (Mills 2007). The $\mathrm{pH}$ of the $\mathrm{H}_{2} \mathrm{O}_{2}$ solution was measured and recorded as 3.25. With the aid of a digital burette, $5 \mathrm{~mL}$ of $0.025 \mathrm{M} \mathrm{NaOH}$ was added and the $\mathrm{pH}$ value raised to 4.65 . The accurately weighed 2.5 -g pulverized sample was placed in $500-\mathrm{mL}$ conical flask, $250 \mathrm{~mL}$ of $15 \% \mathrm{H}_{2} \mathrm{O}_{2}$ was added, and watch glass was placed on the top of the flask. The solution was left under a fume hood for at least $2 \mathrm{~h}$ while reactions continued (until no further bubbles or gas were released) and then placed in a $70^{\circ} \mathrm{C}$ water bath. The heating procedure served to remove excess peroxide and to reveal the current neutralizing ability of the sample (Stewart et al. 2006). The solution was left in the bath for at least $2 \mathrm{~h}$ or until the reactions were complete, then removed and left to cool. When the solution reached ambient temperature, $\mathrm{pH}$ value of the solution $(\mathrm{NAGpH})$ was measured and recorded before titration with standardized $\mathrm{NaOH}$. Miller et al. (1997) stated that if the solution $\mathrm{pH}$ exceeded 2.5, $0.1 \mathrm{M} \mathrm{NaOH}$ should be employed; otherwise, $0.5 \mathrm{M} \mathrm{NaOH}$ should be chosen. Pure water was added to bring final volume up to $250 \mathrm{~mL}$ and the solution was back-titrated to $\mathrm{pH} 4.5$ and then $\mathrm{pH} 7$ to determine the net acidity produced by the acid-generating and acid-neutralizing reactions occurring in the sample (NAG), as outlined in Lawrence (1990) and Miller (2000) (Akabzaa et al. 2007):

$\mathrm{NAG}=\frac{49 \times v_{\mathrm{B}} \times b_{\mathrm{M}}}{s_{\mathrm{W}}}$

where NAG is the net acid generation $\left(\mathrm{kg} \mathrm{H}_{2} \mathrm{SO}_{4} \mathrm{t}^{-1}\right), v_{\mathrm{B}}$ is the volume of the base $(\mathrm{mL}), b_{\mathrm{M}}$ is the molarity of base $(\mathrm{M})$, and $s_{\mathrm{W}}$ is the mass of sample $(\mathrm{g})$.

Geochemical analysis

Mine waste and sedimentary and volcanic rocks were analyzed for total $\mathrm{S}$ and major element content at ACME Laboratories (Canada). Major and trace element concentrations were determined by inductively coupledplasma mass spectrometry (SCIEX-ELAN 9000; PerkinElmer). Total S was determined via infrared adsorption using a LECO $\mathrm{C}-\mathrm{S}$ analyzer. Mineralogical analyses of coal, claystone, mine waste, and volcanic rock samples were performed by X-ray diffraction 
(XRD) using a Philips PW 1830 instrument at the General Directorate of Mineral Research and Exploration Analysis Laboratories in Ankara, Turkey. Scanning electron microscopy (SEM) (Philips FEI XL30-SFEG) coupled with energy-dispersive X-ray spectrometry (EDX) was performed at the Center for Material Science at the Izmir Institute of Technology, Turkey.

\section{Results and discussion}

Mineralogical and geochemical characterization of rock samples and mine wastes

The geology of the study area and its immediate vicinity has created a suitable environment for numerous mineral deposits. Coal and kaolin are two economically important resources extracted from the region. According to geochemical data, the $\mathrm{SiO}_{2}$ content of the andesite rocks ranged from 55.9 to $57.2 \%$, with $\mathrm{Al}_{2} \mathrm{O}_{3}$ of $17.6-18.2 \%$ and $\mathrm{Fe}_{2} \mathrm{O}_{3}$ of $6.9-8.0 \%$ (Table 2). XRD analyses of the argillic altered andesite samples indicated that these included kaolinite, pyrite, and illite/mica-, feldspar-, and smectite-group minerals (Table 3). Yigit (2009) concluded that alteration zones of Can volcanic rocks contained a large volume of disseminated and fracture-fill pyrite. Argillicaltered andesite rock, which includes cubic pyrite crystals smaller than $1 \mu \mathrm{m}$, was observed by SEM (Sanliyuksel Yucel et al. 2016).

Oxides of the major elements in Can coals are dominated by $\mathrm{SiO}_{2}(24.8-30.1 \%), \mathrm{Al}_{2} \mathrm{O}_{3}(10.4-14.8 \%)$,
$\mathrm{Fe}_{2} \mathrm{O}_{3}(5.5-6.3 \%$ ), and others, including $\mathrm{MgO}, \mathrm{CaO}$, $\mathrm{NaO}_{2}, \mathrm{TiO}_{2}, \mathrm{~K}_{2} \mathrm{O}, \mathrm{P}_{2} \mathrm{O}_{5}, \mathrm{MnO}$, and $\mathrm{Cr}_{2} \mathrm{O}_{3}$, each of which comprise less than $1.0 \%$. The minerals present in the coal samples comprised quartz, kaolinite, amorphous matter, pyrite, gypsum, cristobalite, and smectite-, zeolite-, and feldspargroup minerals. The total inorganic mineral content of the coal was $19 \%$, comprising $5.0 \%$ gypsum, $4.8 \%$ pyrite, $4.5 \%$ kaolinite, $3.7 \%$ quartz, and $0.9 \%$ smectite-group clay minerals (Tuncali et al. 2002). Pyrite is observed in framboidal and cubic crystal forms and common mineral in Can formation coal. Lustrous pyrite was observed in macroscopic quantities (Fig. 3a). Well-developed euhedral pyrite crystals are shown by SEM (Fig. 3b), containing $65.3 \% \mathrm{~S}$ and $34.7 \% \mathrm{Fe}$, as quantified by EDX analysis (Fig. 3c). Total S content of the coal ranged from 3.97 to $6.04 \mathrm{wt} \%$; organic S was between 1.6 and $3.0 \%$, pyritic S comprised between 0.65 and $1.10 \mathrm{wt} \%$, and sulfate $\mathrm{S}$ was between 0.85 and $1.54 \mathrm{wt} \%$ (Gurdal 2011). The presence of the high $\mathrm{S}$ content is attributed to the peat environment and regional volcanic activity, as well as to the alkaline depositional environment that has intensive sulfide mineralization (Gurdal and Bozcu 2011).

The major oxides in claystone, located in the same depositional environment with coal, are dominated by $\mathrm{SiO}_{2}(48.0-52.3 \%), \mathrm{Al}_{2} \mathrm{O}_{3}$ (15.2$18.2 \%)$, and $\mathrm{Fe}_{2} \mathrm{O}_{3}(3.0-4.1 \%)$. XRD analyses of the claystone indicated that this composed of kaolinite group minerals, opal-CT, quartz, pyrite, feldspar-group minerals, and gypsum. Sulfur layers associated with iron oxide in Can formation can be easily distinguished in the field indicated by the

Table 2 Major element concentrations of rocks and mine wastes (\%)

\begin{tabular}{llllllllllllll}
\hline Sample name & $\mathrm{SiO}_{2}$ & $\mathrm{Al}_{2} \mathrm{O}_{3}$ & $\mathrm{Fe}_{2} \mathrm{O}_{3}$ & $\mathrm{MgO}$ & $\mathrm{CaO}$ & $\mathrm{Na}_{2} \mathrm{O}$ & $\mathrm{K}_{2} \mathrm{O}$ & $\mathrm{TiO}_{2}$ & $\mathrm{P}_{2} \mathrm{O}_{5}$ & $\mathrm{MnO}^{2}$ & $\mathrm{Cr}_{2} \mathrm{O}_{3}$ & $\mathrm{LOI}^{2}$ & $\mathrm{Sum}^{2}$ \\
\hline Andesite & 55.87 & 17.56 & 6.89 & 1.08 & 3.06 & 2.85 & 3.77 & 0.75 & 0.09 & 0.03 & 0.002 & 7.5 & 99.45 \\
& 57.23 & 18.19 & 8.04 & 0.56 & 0.92 & 1.01 & 4.31 & 0.65 & 0.10 & 0.08 & 0.003 & 8.7 & 99.79 \\
Coal & 24.78 & 10.4 & 6.25 & 0.18 & 0.89 & 0.25 & 0.44 & 0.12 & 0.10 & 0.01 & 0.004 & 55.9 & 99.32 \\
& 30.12 & 14.75 & 5.46 & 0.25 & 1.16 & 0.29 & 0.33 & 0.36 & 0.05 & 0.01 & 0.005 & 47.1 & 99.88 \\
Claystone & 52.26 & 18.22 & 3.01 & 0.81 & 3.47 & 0.51 & 1.85 & 1.01 & 0.29 & 0.001 & 0.003 & 18 & 99.43 \\
& 48.01 & 15.21 & 4.08 & 0.75 & 4.83 & 0.41 & 1.29 & 0.94 & 0.47 & 0.002 & 0.004 & 23.8 & 99.79 \\
Mine waste & 44.61 & 14.13 & 6.57 & 2.09 & 0.22 & 1.14 & 0.93 & 0.64 & 0.14 & 0.002 & 0.004 & 28.9 & 99.37 \\
& 46.50 & 13.9 & 4.85 & 1.44 & 0.41 & 1.27 & 1.39 & 0.17 & 0.08 & 0.001 & 0.004 & 29.2 & 99.21 \\
& & & & & & & & & & & &
\end{tabular}


Table 3 XRD results of rocks and mine wastes

\begin{tabular}{ll}
\hline Sample name & Explanations \\
\hline Andesite & Kaolinite, quartz, illite/mica-group minerals, feldspar-group minerals, pyrite \\
& Kaolinite, smectite-group minerals, pyrite, feldspar-group minerals, illite/mica-group minerals \\
Quartz, opal-CT, gypsum, pyrite, kaolinite, mica/illite, smectite-group minerals, feldspar-group minerals \\
Kaolinite, amorphous matter, quartz, pyrite, gypsum, zeolite-group minerals \\
Kaolinite-group minerals, opal-CT, quartz, pyrite, feldspar-group minerals, gypsum \\
Kaolinite-group minerals, cristobalite, quartz, opal-CT, gypsum, pyrite \\
Quartz, cristobalite, amorphous matter, kaolinite-group minerals, alunite, feldspar-group minerals, \\
Mine waste & illite/mica-group minerals, chlorite-group minerals, pyrite, gypsum \\
& Kaolinite-group minerals, illite/mica-group minerals, opal-CT, gypsum, quartz chlorite-group minerals, \\
& feldspar-group minerals, pyrite, jarosite, goethite
\end{tabular}

yellow color (Fig. 4a). Jarosite exhibits small $(<1 \mu \mathrm{m})$ and sub-rounded crystals in SEM images (Fig. 4b). EDX analysis of the mineralized S layer shown in Fig. 4c indicated that Fe, S, K, and $\mathrm{O}$ are the main components.
The major oxides in mine waste were dominated by $\mathrm{SiO}_{2}, \mathrm{Al}_{2} \mathrm{O}_{3}$, and $\mathrm{Fe}_{2} \mathrm{O}_{3}$, in the ranges of 44.6-46.5, 13.9-14.1, and 4.9-6.5\%, respectively. The mine wastes generally contained quartz, cristobalite, pyrite, opal-CT, gypsum, and illite/mica-, kaolinite-, chlorite-,
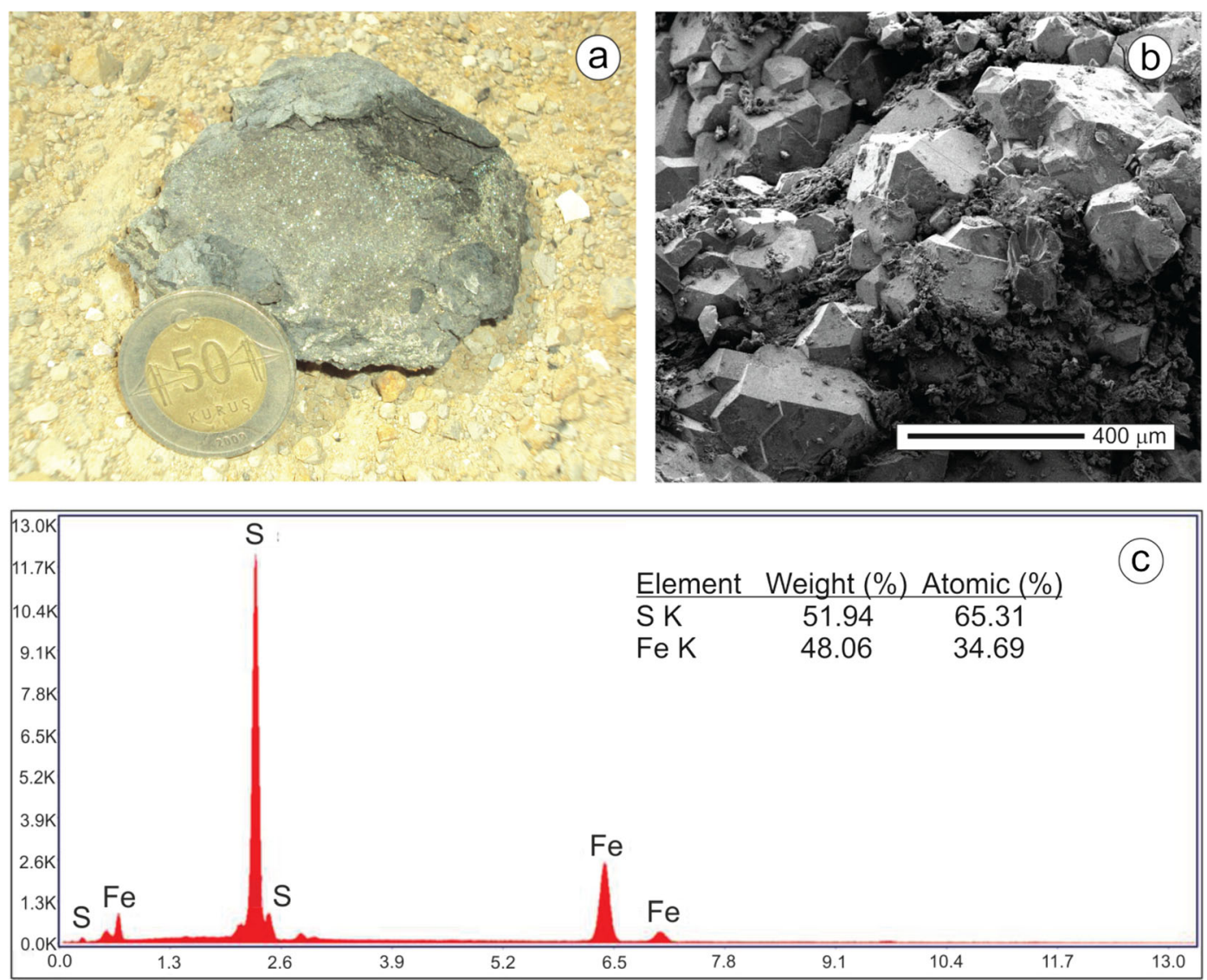

Fig. 3 a Field view, b SEM image, and c EDX spectra of cubic pyrite crystals in coal 

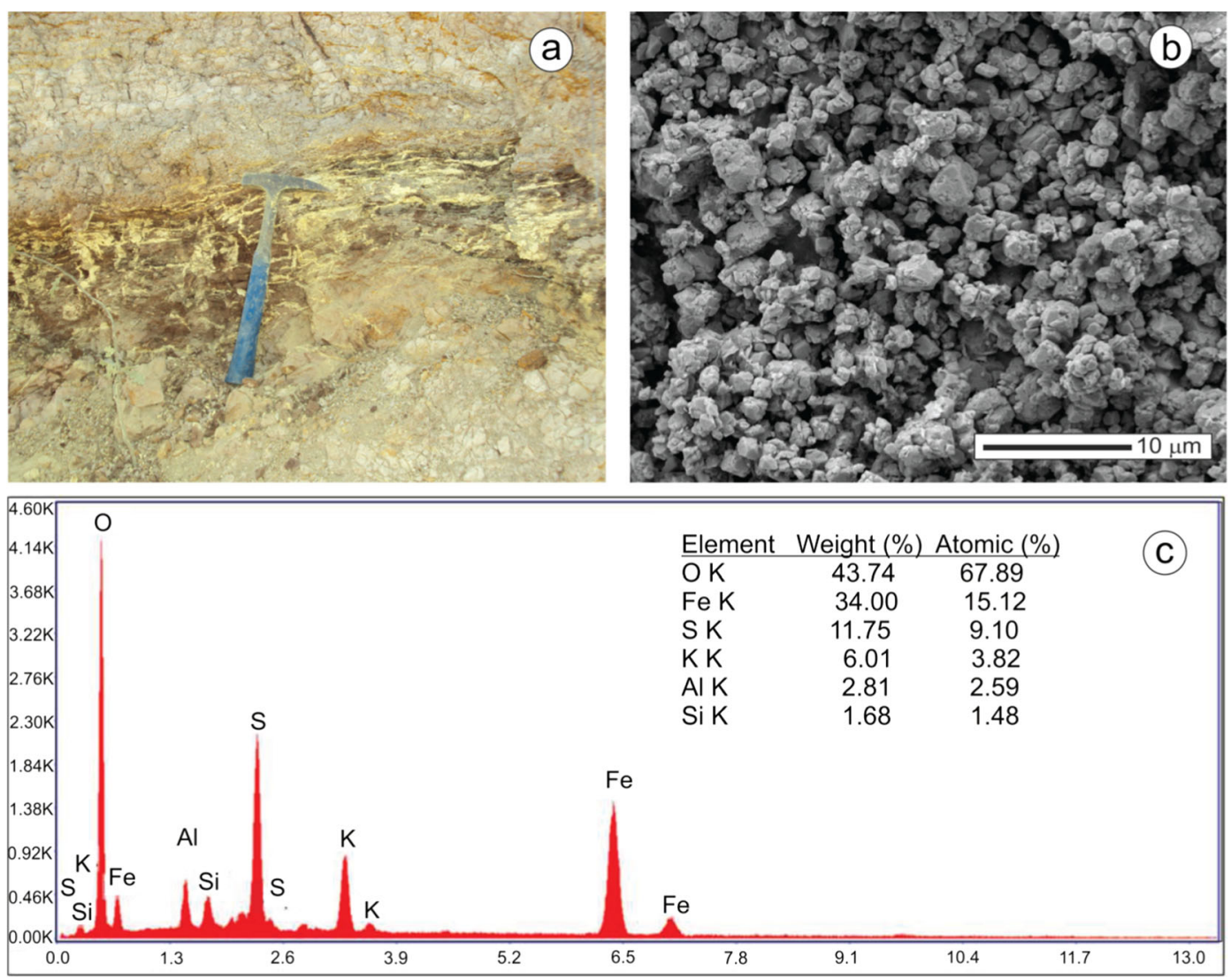

Fig. 4 a Sulfur layer associated with iron oxide in Can formation. b SEM image of jarosite. $\mathbf{c}$ EDX spectra of jarosite containing aluminum silicate

and feldspar-group minerals, in addition to jarosite and alunite. The mine wastes contained $1.69 \%$ total $\mathrm{S}$, including $0.35 \%$ pyritic $\mathrm{S}, 0.71 \%$ sulfate $\mathrm{S}$, and $0.63 \%$ organic S. The total area of mine wastes around Etili coal mine was calculated approximately $1 \mathrm{~km}^{2}$ using satellite images in 2013 (Sanliyuksel Yucel and Yucel 2016). The mine waste consists of sand to silt-clay in particle size (29 to $76 \%$ passing a $75-\mu \mathrm{m}$ sieve). Because of mining activities, shrinkage of the grain size and increasing of the surface area of this geological unit have the potential to accelerate the acid generation process by facilitating the oxidation of sulfide minerals.

Hutt and Morin (1999) stated that if the total S content of a rock is greater than $0.3 \%$, it oxidizes rapidly if exposed to water and oxygen and may produce AMD. In this study area, the total S content of the rock samples and mine waste ranged from 0.08 to $6 \%$. Altered volcanic rocks, coal, and mine wastes $\left(\sum \mathrm{S}>0.3 \%\right)$ therefore have a strong capacity for AMD generation. All investigated lithologies contained pyrite minerals; the mine wastes also contained highly soluble metal sulfates, such as jarosite and alunite minerals, which provide further acidity. Secondary minerals may control the composition of AMD. Gypsum probably occurs as a consequence of secondary oxidation of sulfides. Gypsum, iron hydroxides, and other secondary minerals that have slowly precipitated on the surface of the pyrite can form a coating that may impede further reaction with water and oxygen (Villeneuve et al. 2003).

Carbonate minerals are the largest source of neutralization potential in extractive waste (Kaartinen and Wahlström 2009). Calcite is the most important neutralizing agent because of its common occurrence in a wide range of geological environments and its rapid reaction rate (Lottermoser 2010). Paktunc (1999) stated that a waste material to be considered as having no AMD potential, it must contain at least 
12 times as much calcite as pyrite. Carbonate minerals were, however, not determined by geochemical analysis in these samples: only silicate minerals, such as chlorite, feldspar, kaolinite, mica, quartz, zeolite, and opal-CT, were identified. It is known from field observations, and has been quantified in laboratory studies, that most silicates and aluminosilicates react slowly relative to the rates of sulfide oxidation and carbonate dissolution (Jambor et al. 2002).

Acid generation prediction using static tests

\section{Paste $\mathrm{pH}$ and electrical conductivity}

The paste $\mathrm{pH}$ is indicative of the present drainage of $\mathrm{pH}$ of a sample and acidic drainage will only result when the rate of acid generation exceeds the rate of acid neutralization (Price 2009). The paste $\mathrm{pH}$ of the mine waste samples ranged from 2.3 to 3.8 (Table 4), and this value is similar to $\mathrm{pH}$ value of creeks around Etili coal mine reported by previous studies. The lowest paste $\mathrm{pH}$ value of 2.1 was measured in coal. The paste $\mathrm{pH}$ value of volcanic rock samples ranged from 3.1 to 8.3. Unaltered andesite (sample 5) had a $\mathrm{pH}$ value of 8.3, indicating no risk for acid generation potential. Paste $\mathrm{pH}$ values of selected samples (argillicaltered andesite, coal, and claystone) were less than the critical level of $\mathrm{pH} 4.0$, implying that considerable dissolution occurred within the first 10 min (Table 5). Initial low $\mathrm{pH}$ can be related to oxidation that occurs on the surface of the material. A slight increase in $\mathrm{pH}$ with time indicated the dissolution of neutralizing minerals. The presence of late-dissolving silicate minerals may be indicated. EC value of the solutions increased with time. The highest EC value $\left(6045 \mu \mathrm{S} \mathrm{cm} \mathrm{cm}^{-1}\right)$ was measured in coal at the end of the third week (Fig. 5 and Table 5), indicating that the highest ion transfer to water occurred from coal. The $\mathrm{pH}$

Table 4 Summary of the static test results

\begin{tabular}{|c|c|c|c|c|c|c|c|c|c|c|c|c|c|}
\hline \multirow[t]{2}{*}{$\begin{array}{l}\text { Sample } \\
\text { Name }\end{array}$} & \multirow[t]{2}{*}{ Lithology } & \multirow[t]{2}{*}{ Alteration } & \multirow[t]{2}{*}{$\begin{array}{l}\text { Paste } \\
\mathrm{pH}\end{array}$} & \multirow{2}{*}{$\begin{array}{l}\mathrm{EC} \\
\mu \mathrm{S} \mathrm{cm}^{-1}\end{array}$} & \multirow{2}{*}{$\begin{array}{l}\text { Total } \\
\text { sulfur } \\
\text { wt } \%\end{array}$} & \multirow{2}{*}{\multicolumn{2}{|c|}{$\begin{array}{l}\mathrm{MAP} \mathrm{NP} \\
\mathrm{kg} \mathrm{CaCO}_{3} \mathrm{t}^{-1}\end{array}$}} & \multirow[t]{2}{*}{ NNP } & \multirow[t]{2}{*}{ NPR } & \multirow[t]{2}{*}{$\mathrm{NAGpH}$} & \multicolumn{2}{|c|}{$\begin{array}{l}\text { NAG } \\
\left(\mathrm{kg} \mathrm{H}_{2} \mathrm{SO}_{4} \mathrm{t}^{-1}\right)\end{array}$} & \multirow[t]{2}{*}{$\begin{array}{l}\text { AMD } \\
\text { classification }\end{array}$} \\
\hline & & & & & & & & & & & $\mathrm{pH}=4.5$ & $\mathrm{pH}=7$ & \\
\hline 1 & Andesitic tuff & Argillic & 3.1 & 1285 & 1.70 & 53.12 & 2.05 & -51.07 & 0.03 & 2.91 & 13.48 & 32.57 & PAF \\
\hline 2 & Andesite & & 3.9 & 1070 & 1.16 & 36.25 & 2.47 & -33.77 & 0.06 & 3.56 & 6.40 & 29.41 & PAF \\
\hline 3 & Andesite & Silicic & 5.5 & 417 & 0.22 & 6.87 & 4.32 & -2.55 & 0.62 & 4.02 & 4.91 & 24.95 & PAF \\
\hline 4 & Andesite & Unaltered & 6.5 & 264 & 0.11 & 3.43 & 60.87 & 57.43 & 17.70 & 4.85 & - & 16.11 & NAF \\
\hline 5 & & & 8.3 & 122 & 0.08 & 2.50 & 67.87 & 65.37 & 27.15 & 5.60 & - & 8.58 & NAF \\
\hline 6 & & & 6.9 & 135 & 0.17 & 5.31 & 81.12 & 75.81 & 15.27 & 4.62 & - & 11.62 & NAF \\
\hline 7 & Claystone & - & 3.0 & 1640 & 1.03 & 32.18 & 0.65 & -31.53 & 0.02 & 2.75 & 15.38 & 38.41 & PAF \\
\hline 8 & & & 3.9 & 958 & 0.42 & 13.12 & 1.35 & -11.77 & 0.10 & 3.40 & 5.29 & 27.53 & PAF \\
\hline 9 & Coal & & 2.4 & 2890 & 4.02 & 125.62 & 0.32 & -125.3 & 0.002 & 2.13 & 25.81 & 45.57 & PAF \\
\hline 10 & & & 2.1 & 3510 & 5.98 & 186.87 & 0.22 & -186.65 & 0.001 & 1.72 & 27.36 & 50.23 & PAF \\
\hline 11 & Mine waste & & 3.2 & 1295 & 0.71 & 22.18 & 2.10 & -20.08 & 0.09 & 2.72 & 19.28 & 36.08 & PAF \\
\hline 12 & & & 3.8 & 960 & 0.65 & 20.31 & 0.97 & -19.33 & 0.04 & 3.12 & 8.23 & 27.00 & PAF \\
\hline 13 & & & 2.3 & 3135 & 2.74 & 85.62 & 2.02 & -83.6 & 0.02 & 2.68 & 23.22 & 44.59 & PAF \\
\hline 14 & & & 2.7 & 2260 & 1.38 & 43.12 & 3.07 & -40.05 & 0.07 & 2.99 & 13.07 & 34.12 & PAF \\
\hline 15 & & & 2.6 & 2450 & 1.07 & 33.43 & 2.07 & -31.362 & 0.06 & 3.18 & 9.76 & 30.71 & PAF \\
\hline 16 & & & 2.5 & 2710 & 1.69 & 52.81 & 1.37 & -51.43 & 0.02 & 3.01 & 10.64 & 29.18 & PAF \\
\hline 17 & & & 2.7 & 2325 & 1.27 & 39.68 & 1.82 & -37.86 & 0.04 & 3.10 & 8.31 & 28.94 & PAF \\
\hline Minimun & & & 2.1 & 122 & 0.08 & 2.50 & 0.22 & -186.65 & 0.001 & 1.72 & 4.91 & 8.58 & \\
\hline Median & & & 3.1 & 1295 & 1.07 & 33.43 & 2.05 & -31.53 & 0.06 & 3.10 & 11.85 & 29.41 & \\
\hline Maximur & & & 8.3 & 3510 & 5.98 & 186.87 & 81.12 & 75.81 & 27.15 & 5.60 & 27.36 & 50.23 & \\
\hline
\end{tabular}

$P A F$ potentially acid forming, $N A F$ non-acid forming 
Table 5 Paste $\mathrm{pH}$ and EC values of some selected samples

\begin{tabular}{|c|c|c|c|c|c|c|}
\hline \multirow[t]{2}{*}{ Time (h) } & \multicolumn{3}{|c|}{ Paste $\mathrm{pH}$} & \multicolumn{3}{|c|}{$\mathrm{EC}\left(\mu \mathrm{S} \mathrm{cm}{ }^{-1}\right)$} \\
\hline & Coal & Clay & $\begin{array}{l}\text { Andesite } \\
\text { (argillic altered) }\end{array}$ & Coal & Clay & $\begin{array}{l}\text { Andesite } \\
\text { (argillic altered) }\end{array}$ \\
\hline 0.16 & 2.2 & 3.9 & 3.2 & 52 & 1060 & 1092 \\
\hline 0.33 & 2.0 & 3.9 & 3.1 & 140 & 1100 & 1190 \\
\hline 1 & 2.0 & 3.8 & 3.1 & 221 & 1107 & 1477 \\
\hline 24 & 1.7 & 3.7 & 3.1 & 2070 & 1118 & 1682 \\
\hline 48 & 1.7 & 3.8 & 3.0 & 3755 & 1182 & 1711 \\
\hline 168 & 1.8 & 3.7 & 3.0 & 5085 & 1610 & 2472 \\
\hline 336 & 1.9 & 3.7 & 3.0 & 5995 & 1837 & 2635 \\
\hline 504 & 1.9 & 3.7 & 3.0 & 6045 & 1901 & 2872 \\
\hline
\end{tabular}

and EC values of selected samples suggested the potential for high acid generation under appropriate conditions.

To ensure that the experimental processes simulated ambient conditions, rain water was sampled during field work in December 2012. The $\mathrm{pH}$ value of rain water was measured as 5.9. The paste $\mathrm{pH}$ test was applied to mine waste using rain water and ultrapure water. When rain water was contacted with waste, the $\mathrm{pH}$ value was 2.5 after $10 \mathrm{~min}$, increasing
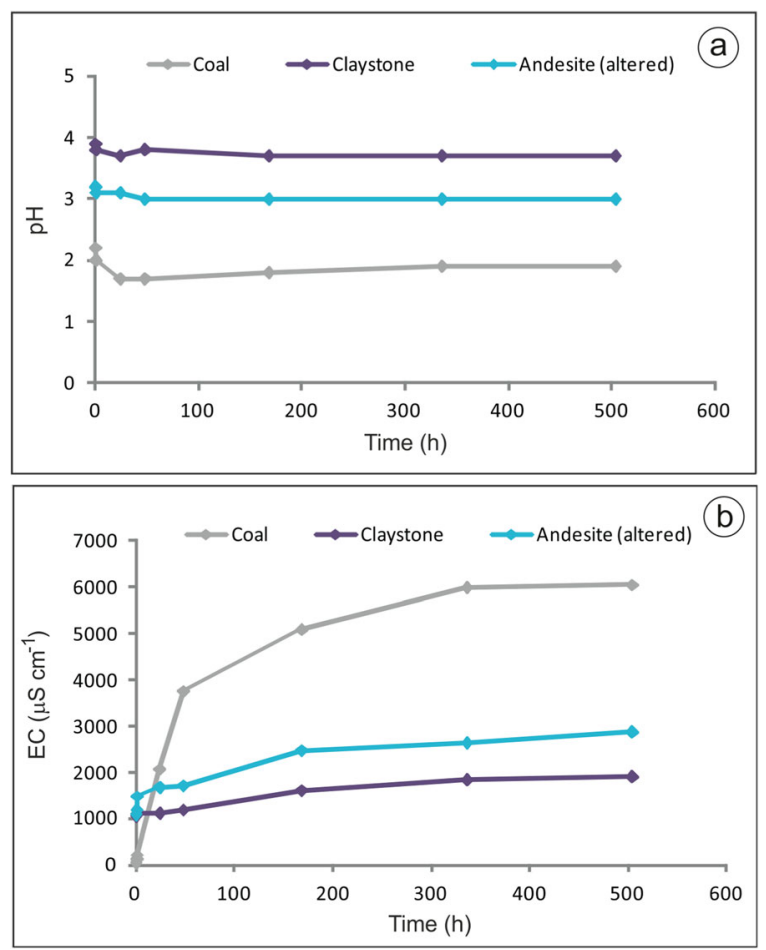

Fig. 5 Time versus a paste $\mathrm{pH}$ and $\mathbf{b} \mathrm{EC}$ values of some selected samples to $\mathrm{pH} 2.7$ in the third week (Table 6). The paste $\mathrm{pH}$ values using rain water and pure water were compatible (Fig. 6). The analogous EC values were also compatible at the end of the third week, reaching maximum values of 4205 and $4395 \mu \mathrm{S} \mathrm{cm}{ }^{-1}$, respectively. The different EC values are attributed to the different initial $\mathrm{pH}$ values of the waters; furthermore, the measurement temperatures and the samples were not completely identical.

\section{Acid-base accounting tests}

Determination of the NP that will be available under ambient conditions is crucial for the development of waste management plans to prevent and control the generation of AMD from mine wastes and other mine components during mining operations and after mine closure (Lawrence and Scheske 1997). The NP values of

Table 6 Paste $\mathrm{pH}$ and EC values of mine waste

\begin{tabular}{|c|c|c|c|c|}
\hline \multirow[t]{2}{*}{ Time (h) } & \multicolumn{2}{|l|}{ Paste $\mathrm{pH}$} & \multicolumn{2}{|c|}{$\mathrm{EC}\left(\mu \mathrm{S} \mathrm{cm}^{-1}\right)$} \\
\hline & $\begin{array}{l}\text { Ultra pure } \\
\text { water }\end{array}$ & $\begin{array}{l}\text { Rain } \\
\text { water }\end{array}$ & $\begin{array}{l}\text { Ultra pure } \\
\text { water }\end{array}$ & $\begin{array}{l}\text { Rain } \\
\text { water }\end{array}$ \\
\hline 0.16 & 2.4 & 2.5 & 4200 & 2870 \\
\hline 0.33 & 2.4 & 2.5 & 4395 & 2900 \\
\hline 1 & 2.4 & 2.5 & 4575 & 3185 \\
\hline 24 & 2.4 & 2.6 & 4605 & 3520 \\
\hline 48 & 2.5 & 2.6 & 4485 & 3625 \\
\hline 168 & 2.6 & 2.7 & 4405 & 4000 \\
\hline 336 & 2.6 & 2.7 & 4405 & 4155 \\
\hline 504 & 2.6 & 2.7 & 4395 & 4205 \\
\hline
\end{tabular}



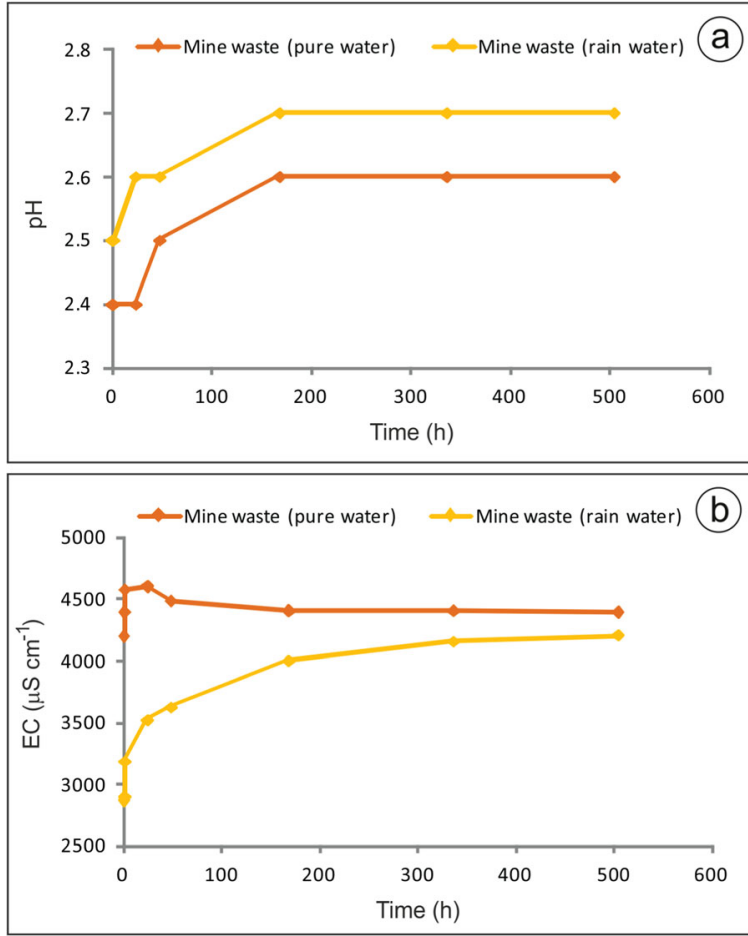

Fig. 6 Time versus a paste $\mathrm{pH}$ and $\mathbf{b} \mathrm{EC}$ values of mine waste

various lithologies in Etili coal mine ranged from 0.22 to 81.12 with a median of $2.05 \mathrm{~kg} \mathrm{CaCO}_{3} \mathrm{t}^{-1}$ (Table 4). Net neutralization potential (NNP) was calculated by subtracting the MAP from NP (Villeneuve et al. 2003). The NNP value is one of the criteria used to determine the acid production potential of a sample (Lottermoser 2010): theoretically, rocks with positive NNP values have no potential for acidification, whereas rocks with negative NNP values do. In practice, a safety factor is applied and rocks with a significantly positive NNP value are generally regarded as having no acidification potential (greater than $+20 \mathrm{~kg} \mathrm{CaCO}_{3} \mathrm{t}^{-1}$ ); rocks with a significant negative NNP value (less than $-20 \mathrm{~kg}$ $\mathrm{CaCO}_{3} \mathrm{t}^{-1}$ ) are potentially acid generating. Materials with intermediate NNP values have uncertain acid generation potential $\left(-20 \mathrm{CaCO}_{3} \mathrm{t}^{-1}<\mathrm{NNP}<+20 \mathrm{~kg}\right.$ $\mathrm{CaCO}_{3} \mathrm{t}^{-1}$ ) (Ferguson and Morin 1991; Miller et al. 1991; Lottermoser 2010). According to this classification, unaltered andesite (samples 4, 5, and 6) had no acidification potential, silicic altered andesite (sample 3) and claystone (sample 8) were uncertain, and all other samples were potentially acid generating.

The neutralization potential ratio (NPR), defined as (NP/MPA) (Price et al. 1997; Mendez-Ortiz et al. 2007), was used as the criterion to evaluate the capacity of a material to generate AMD. If the NPR value is $<1$, the sample is said to be acid generating, and if the NPR is between 1 and $2(1<\mathrm{NPR}<2)$, the sample is considered to be potentially acid generating. If the sample has an NPR between 2 and 4, then it is potentially acid consuming. If the NPR is greater than 4 , the sample is considered to be acid consuming (Price and Errington 1998; Skousen et al. 2002). NPR values ranged between 0.001 and 27.15 , and according to this classification, 14 samples were categorized as acid generating (Fig. 7). The NPR values of unaltered andesite (samples 4, 5 , and 6) were higher than 4 , and these samples were considered to be acid consuming.

According to the assumptions of the ABA test, acid-consuming minerals are completely reacted in nature and the rate of dissolution of acid consumers is the same as that of acid producers. MAP is calculated on the basis of the total S content. The presence of $\mathrm{S}$ in the mineralogical composition of a rock indicates that it may have acid generation potential, but this does not mean that that all $\mathrm{S}$ dissolves completely. Owing to the presence of non-acid-producing S-containing minerals (e.g., gypsum) in the study area, the calculated MAP results were higher than usual. In addition, complete dissolution during the experimental process, especially dissolution of silicate minerals, will never occur: the experimental NP values were therefore lower than the actual values.

\section{Net acid generation test}

According to experimental results of NAG test, oxidation of pyrite, pyrrhotite, arsenopyrite, and chalcopyrite

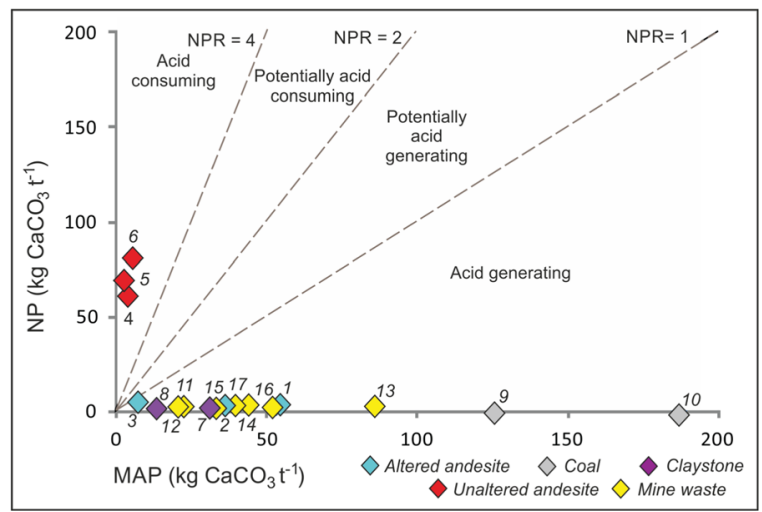

Fig. 7 NPR screening criteria 


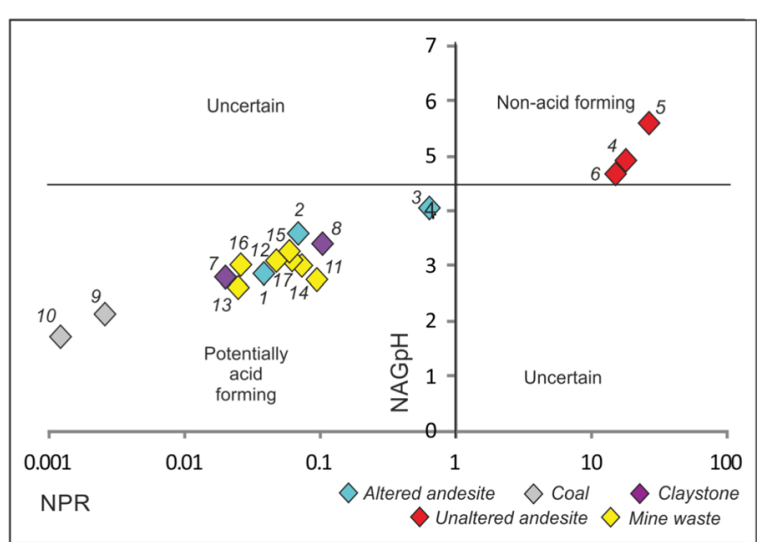

Fig. 8 NPR versus NAGpH

produces a final NAG solution with $\mathrm{pH}$ lower than 4.5 (Stewart et al. 2003). Pyrite is a common mineral in the alteration zones of volcanic rocks, coals, and mine wastes and $\mathrm{NAGpH}$ of these lithologies were measured lower than 4.5 in this study (see Table 4). Charles et al. (2015) stated that in general, a NAGpH less than 4.5 and a NAG value greater than $5 \mathrm{~kg} \mathrm{H}_{2} \mathrm{SO}_{4} \mathrm{t}^{-1}$ are indicative of a potentially acid-forming material. This criterion is compatible with our results.

The samples were subsequently classified using combined ABA/NAG classification system (Fig. 8). NPR was compared with $\mathrm{NAGpH}$ to discriminate between non-acid-forming samples and potentially acid-forming samples. Unaltered andesite (samples 4, 5, and 6) gave non-acid-forming classifications; all other samples were potentially acid forming. NPR results compared reasonably well with NAGpH results for potentially acidforming samples, generally confirming that these may produce acidity on exposure to oxygen and water.

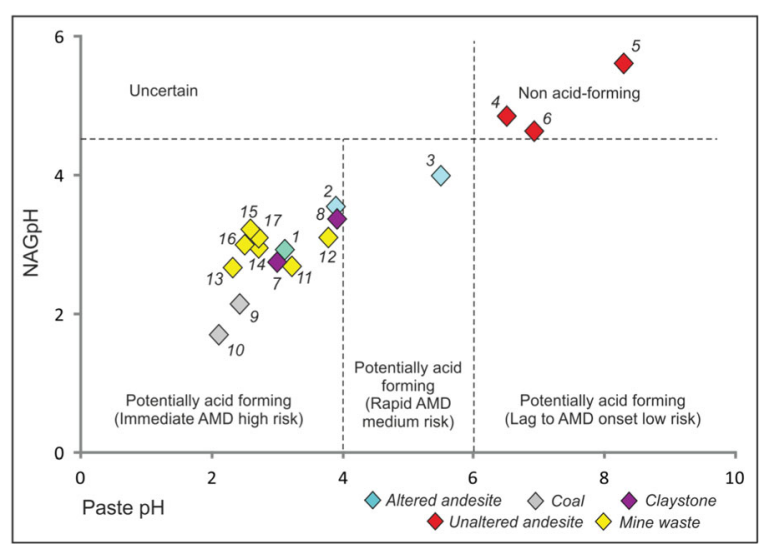

Fig. 9 Paste $\mathrm{pH}$ versus NAGpH
The samples of higher sulfur values lay in the lower left hand quadrant of the paste $\mathrm{pH}$ versus NAGpH classification (Fig. 9) and were potentially acid forming. However, unaltered rocks also lay upper right hand quadrant in the non-acid-forming region. According to this classification, unaltered andesite (samples 4, 5, and 6) was non-acid forming, while silicic altered andesite (sample 3 ) was in the "potentially acid forming (rapid AMD medium risk)" category; all other samples were considered to fall into the "potentially acid forming (immediate AMD high risk)" class. Both results identified unaltered volcanic rocks as non-acid generating.

\section{Conclusions}

AMD generation related to geological and anthropogenic processes is a common environmental problem in many countries, including Turkey. The abundance of pyrite in altered volcanic rocks, coal, and mine wastes was evidenced by field observations and XRD and SEM/EDX analysis. Oxidation of pyrite is the main factor controlling generation of AMD in the Etili region. Because of coal-mining activities, the sulfide minerals are liberated and are present as small particles in mine waste; these oxidize rapidly if exposed to water and oxygen. The generation of AMD is associated with mine wastes that have a major influence on the quality of drainage generated. Carbonate-group minerals were not determined by geochemical analysis. Silicate minerals are slow weathering and cannot effectively lower the acid levels alone. Static test results showed that the mine wastes and altered volcanic and sedimentary rocks, especially coals, have a strong capacity for AMD generation and are defined as potentially acid generating. Unaltered volcanic rocks are non-acid generating. Consistency between results from paste $\mathrm{pH}, \mathrm{ABA}$, and NAG tests was obtained. These tests (supported by geochemical and mineralogical analysis) are sufficient for the preliminary evaluation of AMD possibilities in any mining project in the Etili coal mine.

Acknowledgments The authors would like to thank Dr. Mehmet Karadeniz for his support during laboratory studies and helpful comments. The authors are also grateful to the reviewers for their constructive suggestions. This study was funded by the Teck Mining Company. 


\section{References}

Akabzaa, T. M., Armah, T. E. K., \& Baneong-Yakubo, B. K. (2007). Prediction of acid mine drainage generation potential in selected mines in the Ashanti Metallogenic Belt using static geochemical methods. Environmental Geology, 52(5), 957-964

Banerjee, D. (2014). Acid drainage potential from coal mine wastes: environmental assessment through static and kinetic tests. International Journal of Environmental Science and Technology, 11, 1365-1378.

Benzaazoua, M., Bussiere, B., Dagenais, A. M., \& Archambault, M. (2004). Kinetic tests comparison and interpretation for prediction of the Joutel tailings acid generation potential. Environmental Geology, 46, 1086-1101.

Brough, C. P., Warrender, R., Bowell, R. J., Barnes, A., \& Parbhakar-Fox, A. (2013). The process mineralogy of mine wastes. Minerals Engineering, 52, 125-135.

Bussiere, B., Benzaazoua, M., Aubertin, M., \& Mbonimpa, M. (2004). A laboratory study of covers with capillary barrier effects made of low sulphide tailings to prevent acid mine drainage. Environmental Geology, 45(5), 609-622.

Charles, J. C., Barnes, A., Declerq, J., Warrender, R., Brough, C., \& Bowell, R. J. (2015). Difficulties of interpretation of NAG test results on net neutralizing mine wastes: initial observations of elevated $\mathrm{pH}$ conditions and theory of $\mathrm{CO} 2$ disequilibrium. Proceedings of the 10th International Conference on Acid Rock Drainage and IMWA Annual Conference. Santiago, Chile. April 21-24, IMWA 2015, 1-10.

DiLoreto, Z. A., Weber, P. A., \& Weisener, C. G. (2016). Solid phase characterization and metal deportment in a mussel shell bioreactor for the treatment of AMD, Stockton Coal Mine, New Zealand. Applied Geochemistry, 67, 133-143.

Ercan, T., Satır, M., Sevin, D., \& Turkecan, A. (1995). Interpretation of new chemical, isotopic and radiometric data on Cenozoic volcanic rocks of Western Anatolia. Direct Mineral Research Exploration Bulletin, 119, 103-112.

Ferguson, K. D., \& Morin, K. A. (1991). The prediction of acid rock drainage - lessons from the data base. Proceedings of the 2nd International Conference on Acid Rock Drainage. Montreal, QC, Canada. ICARD 1991, 83-106.

Gunduz, O., \& Baba, A. (2008). Fate of acidic mining lakes in Can lignite district, Turkey. Proceedings of 36th International Association of Hydrogeologists Congress. Toyama, Japan. IAH 2008, 1-7.

Gurdal, G. (2011). Abundances and modes of occurrence of trace elements in the Çan coals (Miocene), Canakkale-Turkey. International Journal of Coal Geology, 87, 157-173.

Gurdal, G., \& Bozcu, M. (2011). Petrographic characteristic and depositional environment of Miocene Çan coals, ÇanakkaleTurkey. International Journal of Coal Geology, 85, 143-160.

Hochella, M. F., Moore, J. N., Golla, U., \& Outnis, A. (1999). A TEM study of samples from acid mine drainage systems: metal-mineral associations with implications for transport. Geochimica et Cosmochimica Acta, 63, 3395-3406.

Hughes, J., Craw, D., Peake, B., Lindsay, P., \& Weber, P. (2007). Environmental characterization of coal mine waste rock in the field: an example from New Zealand. Environmental Geology, 52, 1501-1509.
Hutt, N. M. \& Morin, K. A. (1999). The international static database. Proceedings of Sudbury 99, Mining and the Environment II Conference. Sudbury, Canada. 13-15 September, Volume 1, 363-370.

Jambor, J. L. (2003). Mine-waste mineralogy and mineralogical perspectives of acid-base accounting. In J. L. Jambor, D. W. Blowes, \& A. I. M. Ritchie (Eds.), Environmental aspects of mine wastes (pp. 117-145). Nepean: Mineralogical Association of Canada.

Jambor, J. L., Dutrizac, J. E., Groat, L. A., \& Raudsepp, M. (2002). Static tests of neutralization potentials of silicate and aluminosilicate minerals. Environmental Geology, 43, $1-17$.

Kaartinen, T., \& Wahlström, M. (2009). Development of a European standard for the determination of acid potential and neutralization potential of sulfide waste. Proceedings of 8th International Conference on Acid Rock Drainage and Securing The Future: Mining, Metals \& The Environment in A Sustainable Society. Skelleftea, Sweden. 22-26 June, ICARD 2009, 235-241.

Lapakko, K. A. (2002). Metal mine rock and waste characterization tools: an overview. Mining, Minerals and Sustainable Development, 67, 1-31.

Lawrence, R. W. (1990). Prediction of the behavior of mining and processing wastes in the environment. In F. Doyle (Ed.), Proceedings of Western Regional Symposium on Mining and Mineral Processing Wastes, (pp. 115-121). Littleton: Society for Mining, Metallurgy and Exploration

Lawrence, R. W., \& Scheske, M. (1997). A method to calculate the neutralization potential of mining wastes. Environmental Geology, 32, 100-106.

Lottermoser, B. G. (2010). Mine wastes: characterization, treatment, and environmental impacts. Heidelberg: SpringerVerlag.

Mendez-Ortiz, B. A., Carrillo-Chávez, A., \& Monroy-Fernández, M. G. (2007). Acid rock drainage and metal leaching from mine waste material (tailings) of a $\mathrm{Pb}-\mathrm{Zn}-\mathrm{Ag}$ skarn deposit: environmental assessment through static and kinetic laboratory tests. Revista Mexicana de Ciencias Geológicas, 24, 161-169.

Miller, S. (1998). Prediction predicting acid drainage groundwork. Australian Minerals \& Energy Environment Foundation. https://www.dlsweb.rmit.edu.au/ conenv/envi1128/Groundwork\%20website/publicat/ gw/grnd998/gpredict.htm. Accessed 24 June 2016.

Miller, P. C. (2000). Potential methods for reducing cyanide consumption for bacterial oxidation residues. International document release, BacTech Mining Corporation, 17 November 2000.

Miller, S. D., Jeffery, J. J., \& Murray, G. S. C. (1990). Identification and management of acid generating mine wastes - procedures and practices in South-East Asia and the Pacific Regions. In J. W. Gadsby, J. A. Malick, \& S. J. Day (Eds.), Acid mine drainage designing for closure (pp. 111). Vancouver: BiTech Publishers.

Miller, S. D., Jeffery, J. J., \& Wong, J. W. C. (1991). Use and misuse of the acid base account for AMD prediction. Proceedings of the 2nd International Conference on Acid Rock Drainage. Montreal, QC, Canada. ICARD 1991, 489506. 
Miller, S., Robertson, A., \& Donohue, T. (1997). Advances in acid drainage prediction using the net acid generation (NAG) test. Proceedings of 4th International Conference on Acid Rock Drainage. Vancouver, Canada. ICARD 1997, 535-549.

Mills, C. (2007). Acid-Base Accounting (ABA) test procedures. http://technology.infomine.com/enviromine/ard/Acidbase\%20Accounting/acidbase.htm. Accessed 24 June 2016.

Mitchell, P. (2000). Prediction, prevention, control and treatment of acid rock drainage. In A. Warhurst \& L. Noronha (Eds.), Environmental policy in mining: corporate strategy and planning for closure (pp. 117-143). Boca Raton: Lewis Publishers.

Morin, K. A., \& Hutt, N. M. (1997). Environmental geochemistry of mine site drainage: practical and case studies. Canada: MDAG Publishing.

Morin, K. A., \& Hutt, N. M. (2001). Prediction of water chemistry in mine lakes: the mine wall technique. Ecological Engineering, 17, 125-132.

Morin, K. A., \& Hutt, N. M. (2006). Case studies of costs and longevities of alkali-based water-treatment plants for ARD. Proceedings of the 7th International Conference on Acid Rock Drainage. St Louis, USA. ICARD 2006, 1333-1344.

Okumusoglu, D., \& Gunduz, O. (2013). Hydrochemical status of an acidic mining lake in Can-Canakkale, Turkey. Water Environment Research, 85(7), 604-620.

Paktunc, A. D. (1999). Mineralogical constraints on the determination of neutralization potential and prediction of acid mine drainage. Environmental Geology, 39(2), 103-112.

Price, W.A. (2009). Prediction manual for drainage chemistry from sulphidic geologic materials. MEND Report 1.20.1. December. http://www.fs.usda.gov/Internet/FSE DOCUMENTS/stelprdb5336546.pdf. Accessed $2 \overline{4}$ June 2016.

Price W. A., \& Errington, J. C. (1998). Guidelines for metal leaching and acid rock drainage at minesites in British Columbia, Ministry of Energy and Mines. In mine drainage and surface mine reclamation, 1 : mine water and mine waste. April 19-21. Pittsburgh, USA.

Price, W. A., Morin, K., \& Hutt, N. (1997). Guidelines for the prediction of acid rock drainage and metal leaching for mines in British Columbia: part II-recommended procedures for static and kinetic testing. Proceedings of 4th International Conference on Acid Rock Drainage. Vancouver, Canada. ICARD 1997, 15-30.

Ritcey, G. M. (1989). Tailings management: problems and solutions in the mining industry. Amsterdam: Elsevier Science Publishers.

Sanliyuksel Yucel, D., \& Baba, A. (2013). Geochemical characterization of acid mine lakes and their effect on the environment, NW of Turkey. Archives of Environmental Contamination and Toxicology, 64(3), 357-376.

Sanliyuksel Yucel, D., \& Yucel, M. A. (2016). Determining hydrochemical characteristics of mine lakes from abandoned coal mines and 3D modeling of them using unmanned aerial vehicle. Pamukkale University Journal of Engineering Sciences. doi:10.5505/pajes.2016.37431.

Sanliyuksel Yucel, D., Yucel, M. A., \& Baba, A. (2014). Change detection and visualization of acid mine lakes using time series satellite image data in Geographic Information Systems (GIS): Can (Canakkale) County, NW Turkey. Environmental Earth Sciences, 72(11), 4311-4323.
Sanliyuksel Yucel, D., Balci, N., \& Baba, A. (2016). Generation of acid mine lakes associated with abandoned coal mines in NW Turkey. Archives of Environmental Contamination and Toxicology, 70(4), 757-782.

Sengupta, M. (1993). Environmental impact of mining: monitoring, restoration and control. Boca Raton: Lewis Publishers.

Siyako, M., Burkan, K. A., \& Okay, A. I. (1989). Tertiary geology and hydrocarbon potential of the Biga and Gelibolu Peninsulas. Turkish Association of Petroleum Geologists Bulletin, 1, 183-199.

SKKY (2004). Water pollution control regulation. Official Gazette dated 31.12.2004 and numbered 25687, Ankara, Turkey.

Skousen, J. (1995). Douglas abandoned mine land project: description of an innovative acid mine drainage treatment system. Green Lands, 25(1), 29-38.

Skousen, J., Perry, E., Leavitt, B., Sames, G., Chisholm, W., Cecil, C. B., \& Hammack, R. (2000). Static tests for coal mining acid mine drainage prediction in the eastern U.S. In R. L. P. Kleinmann (Ed.), Prediction of water quality at surface coal mines (pp. 73-98). West Virginia: The National Mine Land Reclamation Center.

Skousen, J., Simmons, J., McDonald, L. M., \& Ziemkiewicz, P. (2002). Acid-base accounting to predict post-mining drainage quality on surface mines. Journal of Environmental Quality, 31, 2034-2044.

Smith, A., Robertson, A., Barton-Bridges, J., \& Hutchison, I. P. G. (1992). Prediction of acid generation potential. In I. P. G. Hutchison \& R. D. Ellison (Eds.), Mine waste management (pp. 123-199). Boca Raton: Lewis Publishers.

Sobek, A. A., Schuller, W. A., Freeman, J. R., \& Smith, R. M. (1978). Field and laboratory methods applicable to overburdens and mine soils. Washington DC: EPA.

Stewart, W., Miller, S., Smart, R., Gerson, A., Thomas, J. E., Skinner, W., Levay, G., \& Schumann, R. (2003). Evaluation of the net acid generation (NAG) test for assessing the acid generating capacity of sulphide minerals. Proceedings of 6th International Conference on Acid Rock Drainage. Cairns, Queensland, Australia. ICARD 2003, 617-625.

Stewart, W.A., Miller, S.D., \& Smart, R. (2006). Advances in acid rock drainage (ARD) characterization of mine wastes. Proceedings of the 7th International Conference on Acid Rock Drainage. St Louis, USA. ICARD 2006, 2098-2119.

Tran, A. B., Miller, S., Williams, D. J., Fines, P., \& Wilson, G. W. (2003). Geochemical and mineralogical characterization of two contrasting waste rock dumps: the INAP waste rock dump characterization project. Proceedings of 6 th International Conference on Acid Rock Drainage. Cairns, Qld., Australia. ICARD 2003, 939-948.

Tuncali, E., Ciftci, B., Yavuz, N., Toprak, S., Koker, A., Aycik, H., Gencer, Z., \& Sahin, N. (2002). Chemical and technological properties of Turkish tertiary coals. Ankara: Directorate of Mineral Research and Exploration's Publication.

U.S. EPA. (1994). Technical document of acid mine drainage prediction. Report No: EPA530-R-94-036, Office of Solid Waste. http://www3.epa.gov/epawaste/nonhaz/industrial/ special/mining/techdocs/amd.pdf. Accessed 24 June 2016.

Usher, B. H., \& Vermeulen, P. D. (2006). The impacts of coal and gold mining on the associated water sources in South Africa. In Y. Xu \& B. Usher (Eds.), Groundwater pollution in Africa (pp. 301-314). Balkema: Taylor \& Francis. 
Villeneuve, M., Bussiere, B., Benzaazoua, M., Aubertin, M., \& Monroy, M. (2003). The influence of kinetic test type on the geochemical response of low acid generating potential tailings. http://www.polymtl.ca/enviro-geremi/pdf/ articles/vilikt(erratum).pdf. Accessed 24 June 2016.

Weber, P. A., Stewart, W. A., Skinner, W. M., Weisener, C. G., Thomas, J. E., \& Smart, R. S. C. (2004). Geochemical effects of oxidation products and framboidal pyrite oxidation in acid mine drainage prediction techniques. Applied Geochemistry, 19, 1953-1974.

Weber, P. A., Hughes, J. B., Conner, L. B., Lindsay, P., \& Smart, R. (2006a). Short-term acid rock drainage characteristics determined by paste $\mathrm{pH}$ and kinetic NAG testing: Cypress prospect, New Zealand. Proceedings of the 7th International Conference on Acid Rock Drainage. St Louis, USA. ICARD 2006, 2289-2295.

Weber, P. A., Skinner, W., Hughes, J. B., Lindsay, P., \& Moore, T. A. (2006a). Source of Ni in coal mine acid rock drainage, West Coast, New Zealand. International Journal of Coal Geology, 67, 214-220.

White, W. W., Lapakko, K. A., \& Cox, R. L. (1999). Static-test methods most commonly used to predict acid-mine drainage: practical guidelines and interpretation. In G. S. Plumlee \& M.
S. Logsdon (Eds.), The environmental geochemistry of mineral deposits, part A: processes, techniques and health issues (pp. 325-338). Littleton: Society of Economic Geologists.

Williams, D. J., Jeffery, J., Gilbert, L., Wilson, G. W., Panidis, C., \& Perry, B. (2003). A review of the acid rock drainage potential and hydrological implications of selectivelyplaced waste rock at a gold mine in NSW, Australia. Proceedings of 6th International Conference on Acid Rock Drainage. Cairns, Qld., Australia. 949-956).

Yeheyis, M. B., Shang, J. Q., \& Yanful, E. K. (2009). Long-term evaluation of coal fly ash and mine tailings co-placement: a site-specific study. Journal of Environmental Management, 91, 237-244.

Yigit, O. (2009). Mineral deposits of Turkey in relation to Tethyan Metallogeny: implications for future mineral exploration. Economic Geology, 104, 19-51.

Younger, P. L., Banwart, S. A., \& Hedin, R. S. (2002). Mine water: hydrology, pollution, remediation. Dorhrecht: Kluwer, Academic.

Yucel, M. A., \& Turan, R. Y. (2016). Areal change detection and 3D modeling of mine lakes using high-resolution unmanned aerial vehicle images. Arabian Journal for Science and Engineering. doi:10.1007/s13369-016-2182-7. 